\title{
Empirical Study on the Integration of Native Culture in English Language Teaching for Non-English Majors in China
}

\author{
Cui-ping Han \\ Department of Foreign Languages, College of Arts and Science, Yangtze University \\ Jingzhou, 434020, Hubei, China \\ Tel: 86-0716-806-8131Ｅ-mail: candyhan2006@163.com
}

[Fund project] The achievement of the 2010 planning fund project for the research of humanities and social sciences sponsored by the Ministry of Education of Hubei province of China (Project Approval Number: 2010b316)

Received: April 1, 2012

doi:10.5539/ells.v2n2p116
Accepted: May 14, 2012

Published: June 1, 2012

\begin{abstract}
The study consists of surveys concerning Chinese culture in English language teaching, which reveal the insufficiency of the input of native culture, the insufficiency of the non-English majors' ability to express Chinese culture in English and the students' attitude toward such insufficiency. Based on the results and analysis, it explores reasons leading to this phenomenon, elaborates the necessity of integrating native culture, and offers some suggestions on English teaching practice. By advocating the integration of native culture in English language teaching for non-English majors, the study is to improve the understanding of cross-cultural communication in culture teaching, thus promoting the cultivation of students' cross-cultural communication competence.
\end{abstract}

Keywords: English Language Teaching, Native culture, Integration, Cross-culture communication

\section{Introduction}

Language is the key media for the translating and spreading of culture. For the trend of economic globalization and the hegemony of English, the teaching of English is gaining more and more support and even emphasis in China. The teaching of English has gained an impressive progress in the past few decades. Most students start to learn English in their teenage and keep learning it in their school life. It has been a consensus that language is correlated with culture. Culture teaching is becoming a main part of English language teaching.

The culture teaching in English teaching is supposed to be about both target culture and native culture for the following reasons: First, cross-cultural communication is a bidirectional process where input and output of information are equally engaged. The goal of foreign language teaching is intercultural understanding and intercultural communication, not only the understanding of another culture but also of one's own culture as well. Given the bidirectionalness of the cross-culture, English learners in our countries are supposed to take English as a media for cross-cultural communicating, including the input and output of information. That is to say, they are to be equipped with both target culture and native culture. Second, the English teaching in China today is the teaching of an international language rather than an average foreign language. English learners are not only to communicate with native speakers of English but also with other people whose mother tongue is not English. Third, with the prosperous development of China, the communication between our country and other countries is booming, which highlights the function of English as a neutral media. Preserving and spreading our native culture will become as vital as absorbing target culture in international communication.

However, most of the culture teaching in colleges and universities in China is one-sided. Most English teachers only pay attention to the introduction of target culture while ignoring the introduction of native culture. It, to a certain extent, impedes the realization of the ultimate goal of foreign language teaching, that is, the cultivation of students' cross-cultural communicative competence. Therefore, efforts must be made to improve culture teaching, thus promoting the students' communicative competence.

As for this aspect, the author conducted a series of surveys concerning Chinese culture in English Language Teaching (ELT) to gain insight into integrating native culture in ELT for Non-English Majors. The subjects in these surveys are all non-English majors. This group is representative and worthy of our attention because they are surely 
of the majority of college students.

\section{Empirical Study}

The relationship between language and culture determines that culture teaching must be included into foreign language education. Meanwhile, the culture teaching should cover both target culture and native culture due to the bidirectionalness and equality principle of cross-cultural communication. The cognitive approach of second language acquisition justifies our further attempt to conduct our surveys from three angles: input, affective filter and output. Is there sufficient native culture in ELT? How does it affect the learners? Can the English learner express the native culture in English? If the students do suffer the "aphasia" for native culture, what are the possible causes? What is the possible solution? Three surveys are conducted to search for the answers to the questions. The relevant research about the output, i.e. the survey on non-English majors' ability in expressing Chinese culture in English has been published in Journal of Yangtze University (Social Science), and this paper is mainly about the other two angles: the input of native culture in ELT and the students' attitude toward integrating native culture into ELT.

\subsection{A Survey on Culture Information in Textbooks}

The output of language is tightly related to the input. If we are eager to assess the English learners' ability in expressing native culture in English, we may first get an overview of how much relevant information they have been exposed to. At the first step, the author conducted survey about culture information in the textbook used in the universities and colleges in Jingzhou in 2009.

At present, the widely-used English textbook at most colleges in Jing Zhou is entitled New Horizon College English, published by Foreign Language Teaching and Research Press (FLTRP). The students finish learning Book One, Two, Three and Four in the four school terms respectively, one book for each term.

\subsubsection{The Insufficiency of Native Culture in the Textbooks}

Table 1 is the statistics about culture content in the textbook. There are ten units on each book, with three passages included in each unit. That is to say, there are totally 30 passages on each book. In Book One, the passages related to the learner's native culture account for 3.33\%. There is only passage which covers a little bit content about China. The Chinese adoption of wind power is mentioned in Trends for the $21^{\text {st }}$ century (Section C, Unit 9) with about twenty words; In Book Two, the passages related to the learner's native culture account for $6.67 \%$. Two passages are related to Chinese culture. Adjustment to a New Culture (Section C, Unit 1) describes the frustrations a Chinese exchange student suffered when facing a new culture. In Finding a Marriage Partner (Section C, Unit 3), the tradition Chinese marriage culture is mentioned. In Book Three, the passages related to the learner's native culture accounts for 3.33\%. How to Prepare for Earthquake (Section A, Unit 6) states the Chinese traditional ways of predicting earthquakes. In Book Four, there is no single passage concerning Chinese issues. In addition, all the passages mentioned here are not mainly aimed at introducing Chinese culture. Take How to Prepare for Earthquake for example, there are only 72 words concerning Chinese ways of predicting earthquakes in the whole passage of 890 words.

To the contrary, the reading materials in these four books widely cover various topics about target culture: the generation gap, gesture, body language, slavery, the usage of guns, Disney, time-consciousness of Americans, the symbols of American culture, the American notions about marriage, the American welfare system, the American business ethics, etc. The list could be continued, for the correlation between language and culture. It has been inferred and confirmed that the English culture has been blended into the language teaching with comparative sufficiency.

The combination of culture learning with language learning is a great progress achieved in ELT. However, from the comparative analysis, we can explicitly conclude the learner's native culture takes up an extremely low percentage in the English textbook. After the survey, a questionnaire about how much native culture students could express in English was conducted.

\subsubsection{The Feasibility of Integrating Native Culture in English Textbooks}

For there has been few practice in China for the sufficient and successful integration of native culture in college English teaching, we have to resort to the practice abroad. Liu Wen has conducted a comparative survey of the native culture content in senior high school English textbooks in China and Japan. The English textbook selected in China is the New Standard English published by Foreign Language Teaching and Research Press (FLTRP) in Beijing in 2006, while the English textbook selected in Japan is New Edition Unicorn English Course/ published by BUN-EIDO in 2006.

Table 2 and Table 3 show us the cultivating of cultural awareness has been laid great attention to in the English 
textbook mentioned above. In addition to some topics for language learning, "Cultural Corner" is to introduce culture in each module. However, it contains no native culture except for the Chinese magnetic suspension train mentioned in the third module.

Things are quite different in the English textbooks in Japan. Of the ten lessons in the whole book, there are four lessons in which Japanese native culture are covered. Lesson2, Lesson5, Lesson 6 and Lesson 10 respectively mention the Japanese sports, Japanese food, Japanese spirit and the culture shock the Japanese experience in Britain.

The English textbooks in Japan set a good example for the integrating of the native culture into ELT. The contrastive analysis shows that they effectually stress the cultivating students' awareness of native culture and take English as a carrier to publicize their native culture.

\subsection{A survey on Non-English Majors' Attitude toward Integrating Native Culture into ELT}

\subsubsection{The Design of the Survey}

As is clearly shown in the first survey, the input about native culture is definitely insufficient. The necessity of integrating native culture is partly proved. With the guide of the previous theoretical background, our following survey is about the students' attitude toward such integrating.

The following five problems are to be discovered in this questionnaire:

(1) What is the most decisive factor affecting the English learning of non-English majors?

(2) What is the students' attitude towards target culture and native culture?

(3) Have the students been aware of the deficiency of native culture in ELT?

(4) If so, do they have the demand to learn more expressions about native culture?

(5) Is there any positive clue that makes it feasible to integrate native culture into ELT?

The questionnaire (see Appendix I) is written in Chinese in order to reduce misunderstanding. It is composed of 15 multiple choices with five scales, $\mathrm{A}=$ strongly agree, $\mathrm{B}=$ agree, $\mathrm{C}=$ neither agree nor disagree, $\mathrm{D}=$ disagree, and $\mathrm{E}=$ strongly disagree. Student subjects are required to choose one that can express their opinion.

\subsubsection{The Distribution and Collection of the Questionnaires}

The survey was launched in Yangtze University, College of Arts and Science. The questionnaires were randomly distributed to 200 non-English majors. 175 questionnaires were collected as callback with 172 being valid.

Before distributing the questionnaire to subjects, several points, apart from the cooperation of English teachers in respective classes, are made clear to guarantee the sincere and serious attitude during the process of finishing questionnaire: (1) giving a brief introduction of the thesis to let them have a clear and preliminary picture of it; (2) all questionnaires are written in Chinese to make sure that subjects can obtain better understanding of the requirements and questions, which can also lessen students' anxiety and provide them with more confidence; (3) making it clear that the results of test questionnaires have nothing to do with their scores examinations so that the subjects are reassured and can keep relaxed all the time; (4) the results of questionnaires will be kept secret; (5) questionnaires are all finished in English class within the given time.

Finally, the data were collected and calculated by the author objectively and carefully. The analysis of investigation uses both quantitative and qualitative methods. The analysis of multiple choices utilizes quantitative method to keep the data accurate. As to the results of questionnaires, the author makes a table according to the 5 categories from the research questions, and then necessary numerical statistics and percentages are calculated in table to present the evident data results. These methods make the result analysis more reliable.

\subsubsection{The Key Findings and Discussion}

The descriptive table (See Table 4) can show the results of questionnaires and help to reach the following conclusions:

(1) The students rely a lot on classroom-teaching in English language learning.

Items 2. 3. 5. 6 and 8 are questions concerning the present state of students' English learning. Totally $51.16 \%$ of the subjects agree that they do spend quite a lot of time studying English after class, but $78.49 \%(24.42 \%$ strongly agree and $54.07 \%$ agree) agree that their acquisition of English are mainly from in-class learning. That is to say, most students rely a lot on classroom-teaching. As for the culture teaching in the textbooks, about half of the students $(52.32 \%)$ disagree that there is sufficient content about Western culture, while the majority of the students $(77.90 \%)$ disagree that there is sufficient content about Chinese culture. 
Textbooks, teachers' instruction and classroom learning count a great part in the non-English majors' English learning. If we need to change a bit in English teaching and learning, the fist step probably lies in the classroom teaching.

(2) The culture teaching in ELT has achieved a lot in cultivating students' cultural awareness.

Items 1.2.3.4 and 11 are questions concerning students' attitude toward culture learning and cultural awareness. It is illustrated that most students show comparatively positive attitude toward culture learning. Most of them agree that learning English is correlated with the learning of the target culture, while $3.49 \%$ neither agree nor disagree and $9.30 \%$ disagree. Most of the students disagree that "learning target culture is more important than spreading native culture in English learning", indicating their awareness of the value of the native culture and concern about bidirectionalness of cross-cultural communication.

There are still some problems. For item 4 "My knowledge about Chinese culture helps me a lot in English learning." Totally, $34.89 \%$ agree, $32.56 \%$ disagree while $32.56 \%$ neither agree nor disagree. Many students underestimate or even neglect the power of native language to the target language learning. The misunderstanding of the role of Chinese culture may lie in the isolating of native culture in English teaching. The positive impact of Chinese culture has been neglected in the textbooks. Many teachers regard Chinese and Chinese culture as only a handicap in English learning, believing that students can learn Standard English by rejecting Chinese in teaching. The teaching syllables, the teacher's instruction are mostly about English culture as well as English language, which mislead students and make them believe that their Chinese proficiency has nothing to do with their English learning.

(3) The students have been aware of the deficiency of the native culture in ELT and willing to change.

Items 3,7,9,12,13 and 15 can show us the students' attitude toward the insufficiency of native culture in EFL. Totally $77.90 \%$ of the subjects agree that there is no sufficient native culture in classroom teaching and learning. The majority of the students (74.42\%) seldom read English materials concerning Chinese culture after class. We may conclude that the English expressions of native culture are almost absent in both the in-class English learning and extracurricular English learning.

Such insufficiency has been detected by the students and they are willing to change. As for item 12 "I often find it difficult to express my own life in English" $16.86 \%$ of students strongly agree and $55.81 \%$ agree, indicating the barrier of expressing native content. Totally $94.77 \%$ of the students (strongly agree $60.47 \%$ and agree $34.30 \%$ ) agree that they want to know more English expressions concerning Chinese culture. The statistics vividly show the need of the students to be exposed to more English materials about the native culture.

(4) English materials concerning Chinese culture are able to lower the affective filter in learning

$68.02 \%$ of the students feel unconfident when communicating with foreigners. Sometimes they are fearful, worried and nervous when they conduct conversation, partly due to the lack of the ability to express native culture. $70.93 \%$ of the students (strongly agree $23.26 \%$, agree $47.67 \%$ ) agree that they are more interested and concentrated when exposed to English material concerning native culture. It indicates that English materials which involve their native culture and are close to their own life help to arouse the students' interest and lower their affective filter in English learning. Second Language Acquisition is a complicated cognitive process whose true causes are comprehensible input and the strength of the filter (Krashen:1993). The subjects' response to the English materials concerning native culture sends positive clues for the feasible innovation in ELT- to integrate native culture in teaching- which may both increase the language competence as well as culture competence. This, correspondingly, proves the necessity of such integration.

\section{Implications for the Integration of Native Culture into ELT}

From the results and discussions shown in Part II, we can find out that it is highly necessary and feasible to integrate native into ELT to the fulfillment of the ultimate goal of English teaching, i.e. the cultivation of students' cross-cultural communicative competence. The inclusion of native culture in the teaching of English poses many challenges for education planners, material designers and English teachers. Given the previous empirical research, this part concentrates on some suggestions for integrating native culture into ELT.

\subsection{Cultivating Students' Culture Awareness}

The survey concerning students' attitude shows previous culture teaching has achieved a lot in cultivating cultural awareness. To some degree, the Non-English majors in China have gained better understanding of the target culture and been more sensitive to the culture differences. However, the empirical study in the paper shows that we still have a long way to go to cultivate culture awareness.

In the global context of Western cultural hegemony, it can be said that elements of western culture have had a very 
influential role on other cultures worldwide with the spread of English as an international language. Up to now, all leading universities have relied primarily on the deep Western pool of wisdom to provide both the method and content of their educational systems. This made sense. Western education created the quite successful societies.

However, just as Kishore Mahbubani states, a revolution is coming in the field of global education. "Now a second Asian cultural awaking is upon us. There is a growing realization that the world can learn a lot from, for say, Chinese and Indian civilization, in everything from poetry and philosophy to traditional medicine and strategic thinking. Paradoxically, leading Western institutions are ahead of their Asian counterparts in grasping this. Yale University, for example, has signed student-exchange agreements with several leading Asian universities, including Peking University." (Kishore Mahbubani: 2005)

Kishore expresses the westerners' demand of learning more from Asian culture. Sadly, most Chinese educators have not fully understood how much the world is changing. "They are comfortable with the old paradigm of copying the West. But as Asian economic development reaches the same level as Western one, this will no longer work" Kishore says, "The educated minds understood both their own culture and the world"

The English language teaching aiming at cross-culture communication in China should also be geared to the change and take the responsibility of spreading the native culture. The students should realize the significance of the native culture. The teachers should rethink what English is to be taught and how it is to be taught in our own local context. The teachers should make ELT useful and meaningful for the students so that English learners are able to experience a sense of pride and achievement in successful second language acquisition

\subsection{Enriching the Input about Chinese Culture in ELT}

From the perspective of the input and output of information in Second Language Acquisition, the outputting is tightly connected to the inputting of information. The survey on culture information in English textbooks shows the deficiency of the inputting of Chinese culture, while the survey about the non-English majors' ability in expressing Chinese culture in English shows the deficiency of outputting of Chinese culture.

The lack of inputting is also attributed to their disability in expressing. The survey concerning students' English ability in expressing proved that if the students are exposed to relevant material, they can do better in expressing and explaining. The factor we should take into consideration is efficient inputting of the information concerning this area. The textbook for College English contains tremendous information concerning the target culture. For the reasons previously mentioned, what needs to be done is the adding of the English version of Chinese Culture to help the students to be familiar with it and be capable of expressing in the practice of cross-culture communication. Throughout the paper, it has been suggested that native culture should be fostered in English language learning experience. In doing so, English language learners get to assume the role of a comparative ethnographer and fully comprehend the role of their own identity during this comparison between their own culture and the target culture. The initial adaptation may lie in the textbook and core test because of their influence and guidance in ELT in China.

Textbooks are the main reliable sources through which teachers conduct English teaching and students learn English to reach the goal. Most students in China, however, are using textbooks in which most passages are written by Americans. The textbooks, however, overemphasize the target culture, while giving much less attention to Chinese culture. As a result, students may be able to talk about American culture in English but are unable to talk about their own culture in English because it has almost never been addressed in their instruction. It is advocated to increase the amount of Chinese culture taught in textbook in order to integrate Chinese culture into EFL teaching. In this way, students become more aware of their own culture and are able to talk about it in English. The English book in Japan mentioned in this paper can serve as a paradigm of the integration of native culture in the English textbooks.

Meanwhile, the role of tests can not be neglected in ELT, even though the assessment of the English Proficiency is a systematical and comprehensive process which is not only about language tests. In fact, most students aim at various certificates to show their language proficiency .As we all know, one of the important objectives of English learning for non-English majors is to pass the examination, especially CET-4 and CET-6. To some degree, such English tests partly determines students' general orientation of English learning.

According to the Syllabus of Test for English Majors-8, "General Knowledge" is aimed at assessing the examinees' general knowledge about English culture, including the geographical conditions, the cultural traditions and literature. The inclusion of culture in the test has proven to stimulate the students to pay more attention to culture learning in the process of language learning. Even though the native culture has still been neglected in the test for English Majors, the form of such culture test is worthy learning and using for reference in the test for non-English majors.

Therefore, in the examinations for non-English majors, especially CET-4 and CET-6, it is advisable that questions about culture including target culture and native culture should be added, which not only helps to cultivate students' 
cross-cultural communicative competence and enhance their ability of expressing Chinese culture in English, but also encourages teachers and students to lay more emphasis on native culture elements. Besides, the oral test of CET-4 and CET-6 may adopt native culture as topics, which is certain to promote the study of native culture in English learning.

\subsection{Strengthening the Teachers' Role}

The main argument the author attempts to articulate is clear by now that native culture should be integrated into the foreign language textbooks and classroom practices. It goes without saying that the teacher plays a key role in culture teaching and learning in EFL classrooms. Course materials effectively used and carefully planned by teachers are important factors in the integration of native culture in ELT.

The problem is that although there is clear requirement in the syllabus for cultural teaching, there are no details for what to teach and how to teach it and no systematic teaching materials for reference. In addition, preparation for cultural teaching is time consuming and requires extremely wide knowledge, which is very difficult for busy and heavy-burdened college English teachers. Many college English teachers consider it a waste of time to teach culture, which is irrelevant to CET 4 or CET 6. Some teachers just read out the cultural background notes from teachers' reference book and are not willing to bother themselves to consult more relevant information or to make the cultural information more vivid and more practical.

It is time to change. As Buttjes notes, language teachers need to go beyond monitoring linguistic production in the classroom and become aware of the complex and numerous processes of intercultural mediation that any foreign language learner undergoes (Buttjes, 1990: 55-56). Chastain stated, "Second language teachers need a definition, a thematic organization, and at least an elementary knowledge of the culture" (Chastain, 1988: 308).

Integrating the native culture into language teaching does not inherently provide a clear-cut framework for teachers. The reason why this process is so fuzzy basically stems from the complex and vast nature of culture. The critical question, at this point, regards what the teachers should focus on within the wide range of topics or operations occurring in a culture. Correspondingly, language teachers should not be misled by the delusion that including native culture in their classrooms is a straightforward act, but should be alert to the fact that selection, development and adaptation of cultural materials or topics require tremendous care to ensure numerous premises. To illustrate, such materials, as Brooks lays out, should be derived from symbolism, values, authority, order, ceremony, love, honor, humor, beauty, and spirit, and should take into consideration and reflect several aspects, such as the life style, uniqueness, common sense, religion, and family values of the speakers and make comparison between that of the target culture and that of the native culture (Brooks, 1975: 19-31).

The responsible and creative teacher can come up with numerous ideas regarding how to integrate native culture into the textbooks and in-class activities such as the lectures about native culture in English, situational activities in class and discussion about the cultural difference. However, it should be noted that the potential activities and strategies are endless, and that each teacher should assess their own context to evaluate the effectiveness of any prospective activity, and should modify any activity or material at hand to fit the students' needs better. The teachers should be qualified not only as foreign language teachers, but as foreign culture teachers. They need to have the ability to analyse both native and target cultures competently and serve as the "mediators of culture teaching" (Singhal, 1998: 27). Through careful planning and wise course material selection, the teachers have the ability to integrate native culture into ELT and promote cultural sensitivity and appreciation among students.

\section{Conclusion}

The teaching of culture in foreign language education is now a heated topic. Both scholars and English teachers have arrived at a consensus that culture teaching in foreign language education is indispensable. The trend of foreign language teaching and research has been shifted from the exploration of developing students' sole linguistic skills to the cultivation of their cross-cultural communicative competence. However, in the field of ELT, English teachers and researchers have misunderstood the content of culture teaching and paid most of their attention to target culture, but ignored learners' native culture. The ignorance of native culture is obvious, which has caused severe problems and aroused more and more attention.

Under the guidance of theories concerning culture teaching and the integration of native culture with target culture in ELT, the author conducted a series of surveys in Yangtze University to probe into this problem. The surveys reveal the insufficiency of the input of native culture in ELT, the insufficiency of the non-English majors' ability to express Chinese culture in English and the students' awareness of such insufficiency. Based on the data collected, the paper proposes that more Chinese cultural knowledge should be presented in English teaching and the teachers should take more responsibilities and make more efforts to improve learners' ability of bidirectional cross-culture 
communication.

The main purpose of this thesis is to draw English educators and teachers' attention to the necessity of integrating of native culture in English teaching for non-English majors, thus promoting the cultivation of students' cross-cultural communicative competence. Moreover, the paper is to shed some light on the feasibility of such integration. Therefore, it has a practical significance.

The author has made great efforts to make the surveys valid and reliable. The questions in questionnaire are written in Chinese in order to reduce the misunderstanding, although it may seem informal. Great work has been done on the arrangement of questionnaires so that it is quite systematically and easily understood. All the subjects were randomly chosen. Data were collected and calculated by the author objectively and carefully.

Yet there are still some limitations. First, the empirical study is conducted only in Jingzhou, and the number of subjects is still far from enough for the systematic study of the research. If the investigation was carried out in different parts of China, perhaps the results would be much more persuasive. Second, owing to the lack of the ready-made materials and the controversial definition of "culture" and "Chinese culture", the questionnaire made by the author herself may have many loopholes. Despite the loopholes, through the subjects' responses to the questionnaire, a general picture of the current state of culture teaching for non-English majors can still be obtained.

The limitations illustrated above are also where the recommendations for further studies lie. Firstly, the design of questionnaire and test paper needs to be improved. Secondly, if possible, a larger sample should be made in order to test and reanalyze the phenomenon. Thirdly, the implementation of such integration deserves more concern. How much native culture should be included and how they can be integrated systematically and successfully are both questions waiting for further study.

\section{References}

Buttjes, D. (1990). Teaching Foreign Language and Culture: Social Impact and Political Significance. Language Learning Journal, 2, 53-57.

Chastain, K. (1988). Developing second-language skills: Theory to practice. Orlando, FL: Harcourt.

Claire Kramsch. (1999). Context and Culture in Language Teaching. Shanghai: Shanghai Foreign Language Education Press.

Cong Cong. Chinese Culture "Aphasia": The Defects of English Education in China. GuangMing Daily. [Online] Available: http://www.gmw.cn/01gmrb/2000-10/19/GB/10^18578^0^GMC1-109.htm

Deng Yaochen. (2007). Review on Learner corpus and the Second Language Acquisition Research. Foreign Language World, 1, 18-23.

Ji Jingtong, \& Song Li. (2005). On the Input of Chinese Culture in College English Teaching. Sino-US English Teaching, 2(3), 58-60. ISSN1539-8072, USA.

Han Cuiping, \& Zheng Houyao. (2008). A Survey on Non-English Majors' Ability in Expressing Chinese Culture in English. Journal of Yangtze University (Social Science), 31(21), 103-106.

Kramsch. C. (1993). Context and culture in language teaching. New York:Oxford University Press.

Kishore Mahbubani. (2005). Can Asians Think? Hai Nan: Hai Nan Press.

Liu Changjiang. (2003). On the Integration of Target Culture and Native Culture in Foreign Language Teaching. Foreign Language World, 4, 14-18.

Liu Shiwen. (2003). Survey and Reflection on EFL learners' ability to present Chinese culrue. Foreign Language Teaching amp Research in Basic Education, 1, 29-31.

Liu Wen. Source Culture and the Compilation of English Language Textbooks for Senior High School in China. Available: http://www.tjjy.com.cn/uploadfiles2/79220090217122359.doc

Nelson Brooks. (1975). The Analysis of Language and Familiar Cultures. The Cultural Revolution in Foreign Language Teaching. In R. C. Lafayette (Ed.), National Textbook Company, 19-31.

Revised Group of Syllabus for TEM 8. Syllabus for TEM 8. Shanghai: Shanghai Foreign Language Education Press, 2004.

Shi Haige. (2005). On the Application of Native Culture in English Language Teaching. [M. S. Dissertation]. Beijing: College of Foreign Languages Capital Normal University.

Singhal, M. Teaching Culture in the Foreign Language Classroom. Thai TESOL Bulletin, 11(1), February 1998. 
Table 1. The content concerning Chinese culture in English textbooks

\begin{tabular}{|c|c|c|}
\hline & Numbers of passages & Percentage \\
\hline Book 1 & 1 & $3.33 \%$ \\
\hline Book 2 & 2 & $6.67 \%$. \\
\hline Book 3 & 1 & $3.33 \%$ \\
\hline Book 4 & 0 & 0 \\
\hline
\end{tabular}

Table 2. The content of one English textbook in China

\begin{tabular}{|c|c|}
\hline Module & Cultural Corner \\
\hline 1 & American School System \\
\hline 2 & School Differences in Different Countries \\
\hline 3 & The Fastest Train in the World \\
\hline 4 & Village Problems in Western Europe \\
\hline 5 & Science Teaching in Canada \\
\hline 6 & Text Messages and Emotions \\
\hline
\end{tabular}

Table 3. The content of one English textbook in Japan

\begin{tabular}{|c|l|}
\hline Lesson & \multicolumn{1}{c|}{ Topic } \\
\hline 1 & You Can Change the World \\
\hline 2 & Unique Sports \\
\hline 3 & Alex the Parrot \\
\hline 4 & Life is so Good \\
\hline 5 & Tofu: a World Favorite \\
\hline 6 & The Great Journey \\
\hline 7 & One Step Beyond \\
\hline 8 & Are we Alone in the Universe \\
\hline 9 & Chagall: a Life of Love and Art \\
\hline 10 & Soseke in London \\
\hline
\end{tabular}

Table 4. The subjects' attitude toward culture teaching in ELT

\begin{tabular}{|c|c|c|c|c|c|c|c|c|c|c|}
\hline \multirow[b]{2}{*}{$\begin{array}{l}\text { Item } \\
\text { No. }\end{array}$} & \multicolumn{2}{|c|}{$\mathrm{A}=$ strongly agree } & \multicolumn{2}{|c|}{$\mathrm{B}=$ agree } & \multicolumn{2}{|c|}{$\begin{array}{c}\mathrm{C}=\text { neither agree } \\
\text { nor disagree }\end{array}$} & \multicolumn{2}{|c|}{$\mathrm{D}=$ disagree } & \multicolumn{2}{|c|}{$\begin{array}{r}\mathrm{E}=\text { strongly } \\
\text { disagree }\end{array}$} \\
\hline & $\begin{array}{c}\text { Numbe } \\
r\end{array}$ & $\begin{array}{c}\text { Percent } \\
\text { age }\end{array}$ & $\begin{array}{c}\text { Numb } \\
\text { er }\end{array}$ & $\begin{array}{c}\text { Percent } \\
\text { age }\end{array}$ & $\begin{array}{c}\text { Numb } \\
\text { er }\end{array}$ & $\begin{array}{c}\text { Percent } \\
\text { age }\end{array}$ & $\begin{array}{c}\mathrm{Nu} \\
\mathrm{mb} \\
\mathrm{er}\end{array}$ & $\begin{array}{c}\text { Percent } \\
\text { age }\end{array}$ & Number & ercentage \\
\hline 1 & 58 & 33.72 & 92 & 53.49 & 6 & 3.49 & 16 & 9.30 & 0 & 0 \\
\hline 2 & 4 & 2.33 & 58 & 33.72 & 20 & 11.63 & 88 & 51.16 & 2 & 1.16 \\
\hline 3 & 4 & 2.33 & 14 & 8.14 & 20 & 11.63 & 124 & 72.09 & 10 & 5.81 \\
\hline 4 & 6 & 3.49 & 54 & 31.40 & 56 & 32.56 & 52 & 30.23 & 4 & 2.33 \\
\hline 5 & 98 & 56.97 & 60 & 34.88 & 6 & 3.49 & 4 & 2.33 & 4 & 2.33 \\
\hline 6 & 14 & 8.14 & 74 & 43.02 & 33 & 19.19 & 50 & 29.07 & 1 & 0.58 \\
\hline 7 & 1 & 0.58 & 3 & 1.74 & 0 & 0 & 73 & 42.44 & 95 & 55.23 \\
\hline 8 & 42 & 24.42 & 93 & 54.07 & 0 & 0 & 37 & 21.51 & 0 & 0 \\
\hline 9 & 26 & 15.12 & 102 & 59.30 & 14 & 8.14 & 24 & 13.95 & 6 & 3.49 \\
\hline 10 & 58 & 33.72 & 59 & 34.30 & 23 & 13.37 & 26 & 15.12 & 6 & 3.49 \\
\hline 11 & 1 & 0.58 & 32 & 18.60 & 23 & 13.37 & 78 & 45.35 & 38 & 22.09 \\
\hline 12 & 29 & 16.86 & 96 & 55.81 & 15 & 8.72 & 25 & 14.53 & 7 & 4.07 \\
\hline 13 & 104 & 60.47 & 59 & 34.30 & 9 & 5.23 & 0 & 0 & 0 & 0 \\
\hline 14 & 40 & 23.26 & 82 & 47.67 & 40 & 23.26 & 10 & 5.81 & 0 & 0 \\
\hline 15 & 8 & 4.65 & 24 & 13.95 & 24 & 13.95 & 88 & 51.16 & 28 & 16.28 \\
\hline
\end{tabular}




\section{Appendix I}

\section{Questionnaire}

This questionnaire is to probe into the current situation of English language teaching and students' attitude towards integrating Chinese culture into English Teaching. The statements in this questionnaire are neutral. The information you provide is for statistical analysis and surely to be kept confidential. Please feel at ease to finish it according to your real feelings and opinions anonymously and then hand it in directly to the questionnaire-distributor. The information you provide will be of great help to our academic research and future teaching. Your support and cooperation will be highly appreciated.

Note: please use the letter A.B.C.D.E to respectively represents: strongly agree, agree, neither agree nor disagree, disagree, strongly disagree

1. Learning English is correlated with the learning of the target culture.

2. There is sufficient content about Western culture in English textbooks.

3. There is sufficient content about Chinese o in English textbooks.

4. My knowledge about Chinese culture helps me a lot in English learning.

5. The class hours for English are more than that of Chinese every week in my class.

6. I spend quite a lot of time studying English after class.

7. Understanding Western culture is sufficient for English learning. Chinese culture is necessary for English learning.

8. My acquisition of English is mainly from textbooks and in-class learning.

9. I seldom read English materials concerning Chinese culture after class.

10. I often feel unconfident when communicating with foreigners in English.

11. Learning western culture is more important than spreading Chinese culture in English learning.

12. I often find it difficult to express my own life in English.

13. I want to know more English expressions concerning Chinese culture and my own life.

14. I am more interested and concentrated when exposed to English material concerning Chinese culture in English learning.

15. The ability of expressing Chinese culture in English can be acquired naturally in the process of learning English. It needs not to be trained specially. 